\title{
Murine sca1/flk1-positive cells are not endothelial progenitor cells, but B2 lymphocytes
}

\author{
Eva Steffen ${ }^{1}\left[\right.$ - Wolfgang Bernd Edziu Mayer von Wittgenstein ${ }^{1} \cdot$ Marie Hennig ${ }^{1}$. Sven Thomas Niepmann ${ }^{1}$. \\ Andreas Zietzer ${ }^{1}$. Nikos Werner ${ }^{5}$. Tienush Rassaf ${ }^{2}$ - Georg Nickenig ${ }^{1}$. Sven Wassmann ${ }^{3,4}$. Sebastian Zimmer ${ }^{1}$. \\ Martin Steinmetz ${ }^{2}$
}

Received: 23 October 2018 / Accepted: 2 January 2020 / Published online: 24 January 2020

(c) The Author(s) 2020

\begin{abstract}
Circulating sca $1^{+} / \mathrm{flk} 1^{+}$cells are hypothesized to be endothelial progenitor cells (EPCs) in mice that contribute to atheroprotection by replacing dysfunctional endothelial cells. Decreased numbers of circulating sca $1^{+} / \mathrm{flk} 1^{+}$cells correlate with increased atherosclerotic lesions and impaired reendothelialization upon electric injury of the common carotid artery. However, legitimate doubts remain about the identity of the putative EPCs and their contribution to endothelial restoration. Hence, our study aimed to establish a phenotype for sca $1^{+} / \mathrm{flk} 1^{+}$cells to gain a better understanding of their role in atherosclerotic disease. In wild-type mice, $\mathrm{sca} 1^{+} / \mathrm{flk} 1^{+}$cells were mobilized into the peripheral circulation by granulocyte-colony stimulating factor (G-CSF) treatment and this movement correlated with improved endothelial regeneration upon carotid artery injury. Multicolor flow cytometry analysis revealed that $\mathrm{sca} 1^{+} / \mathrm{flk} 1^{+}$cells predominantly co-expressed surface markers of conventional B cells (B2 cells). In RAG2-deficient mice and upon B2 cell depletion, sca $1^{+} / \mathrm{flk} 1^{+}$cells were fully depleted. In the absence of monocytes, $\mathrm{sca} 1^{+} / \mathrm{flk} 1^{+}$cell levels were unchanged. A PCR array focused on cell surface markers and next-generation sequencing (NGS) of purified sca $1^{+} / \mathrm{flk} 1^{+}$cells confirmed their phenotype to be predominantly that of $\mathrm{B}$ cells. Finally, the depletion of B2 cells, including sca $1^{+} / \mathrm{flk} 1^{+}$cells, in G-CSF-treated wild-type mice partly abolished the endothelial regenerating effect of G-CSF, indicating an atheroprotective role for sca $1^{+} / \mathrm{flk} 1^{+} \mathrm{B} 2$ cells. In summary, we characterized sca ${ }^{+} / \mathrm{flk} 1^{+}$cells as a subset of predominantly B2 cells, which are apparently involved in endothelial regeneration.
\end{abstract}

Keywords Endothelial progenitor cells $\cdot$ B Lymphocytes $\cdot$ Atherosclerosis $\cdot$ Endothelial dysfunction $\cdot$ Endothelial regeneration

Eva Steffen

Eva.Steffen@ukbonn.de

1 Herzzentrum Bonn, Medizinische Klinik und Poliklinik II, Universitätsklinikum Bonn, Venusberg Campus 1, 53127 Bonn, Germany

2 Westdeutsches Herz- und Gefäßzentrum, Klinik für Kardiologie und Angiologie, Universitätsklinikum Essen, Essen, Germany

3 Cardiology Pasing, Munich, Germany

4 University of the Saarland, Homburg, Saar, Germany

5 Krankenhaus der Barmherzigen Brüder, Innere Medizin III, Trier, Germany

\section{Introduction}

Damage of the endothelium is a main feature of a variety of vascular diseases including atherosclerosis or upon percutaneous transluminal angioplasty. Such damage leads to endothelial dysfunction and finally the deterioration of the endothelial cells, which can further result in plaque progression or restenosis following interventional treatment [5, 12]. The renewal of endothelial cells is crucial to restrain or even prevent the process of atherosclerosis and restenosis. It has been hypothesized that the endothelium is restored in loco by proliferation of neighboring endothelial cells (ECs). This paradigm has been challenged by Asahara and a plethora of later studies, which proposed that circulating endothelial progenitor cells (EPCs) significantly contribute to reendothelialization [1]. Those putative EPCs have been associated with endothelial restoration and have been shown 
to be inversely correlated with atherogenesis in humans and mice $[8,25,28,33,35,36,38]$.

However, the identification of EPCs has been challenging due to the fact that EPCs do not express a specific surface marker and do not demonstrate characteristics that allow for their definitive identification. A variety of surface marker combinations and cell types have been used for the investigation of EPCs, although these markers are also expressed on other cell subsets such as hematopoietic cells or mature endothelial cells $[6,13,15,29]$. Thus, studies investigating EPCs are hard to compare and present conflicting results [42].

In one study, injected sca $1^{+} / \mathrm{flk} 1^{+}$cells were detected in the endothelial layer of the neointima following femoral artery injury [40]. In $\mathrm{ApoE}^{-/-}$mice that have received transplanted bone marrow from eGFP transgenic mice, only 1 cell out of almost 3000 cells analyzed in carotid bifurcation plaques originated from the bone marrow [9]. In a murine model of hindlimb ischemia, bone-marrow-derived stem cells were not incorporated into the vascular wall. Instead, they featured a supportive, paracrine function that supported angiogenesis [44]. We found in previous studies that sca ${ }^{+} /$ flk $1^{+}$cells were mobilized from the bone marrow and correlated with vascular health $[27,28,30]$.

As a consequence of these puzzling results, the identity and function of EPCs as well as their role in endothelial health are still under heavy debate [13, 15, 21].

The identification of the cellular origins of putative EPCs and their pathophysiological involvement in vascular damage and regeneration are pivotal to develop efficient approaches for their use, with a reliable, therapeutic benefit.

In this study, we sought to scrutinize the identity of $\mathrm{sca}^{+} /$ flk $1^{+}$cells, to amend the current hypothesis of vascular regeneration by circulating cells.

\section{Materials and methods}

\section{Animals and treatment regimen}

All experiments were performed in accordance with institutional guidelines and the German animal protection law. 12-week-old male and female C57/B16J mice (Charles River, Wilmington, USA) and 12-week-old female RAG2-deficient mice (The Jackson Laboratory, Bar Harbor, USA) were used in this study. All animals were maintained in a 12-h dark/ light cycle and received water and food ad libitum. Medical treatment, B2 cell depletion and monocyte depletion were performed as indicated below.

For mobilization experiments, 12-week-old C57/B16J mice were randomly assigned to two groups and received G-CSF $\left(0.05 \mu \mathrm{g} / \mathrm{g}\right.$ body weight; Neupogen ${ }^{\circledR}$, AMGEN,
Thousand Oaks, USA) or PBS once per day for 10 days. All substances were administrated intraperitoneally.

For B2 cell depletion, 12-week-old male C57/B16J mice received an intraperitoneal injection of $50 \mu \mathrm{g}$ of an antiCD20 antibody (Ultra-LEAFTM Purified anti-mouse CD20 Antibody, clone SA271G2, Biolegend, San Diego, USA) or an isotype identical control (Ultra-LEAFTM Purified Rat IgG2b, k Isotype Ctrl Antibody, clone RTK4530, Biolegend, San Diego, USA). After 3 days, B2 lymphocytes were almost completely depleted. The application of the antibody was repeated after 7 days. For monocyte depletion, 12-weekold male C57/B16J mice received an intraperitoneal injection of $200 \mu \mathrm{l}$ of clodronate-filled liposomes (clodronate liposomes, $5 \mathrm{mg} / \mathrm{ml}$, Liposoma B.V., Amsterdam, the Netherlands) or PBS-filled control liposomes (Liposoma B.V., Amsterdam, the Netherlands). $24 \mathrm{~h}$ after injection, a nearly complete depletion of classical and non-classical monocytes was achieved. The liposome injection was repeated every other day. B2 cell and monocyte depletions were confirmed by flow cytometry on the day of the carotid artery denudation and on the day of killing. Animals without sufficient B2 cell or monocyte depletion were excluded from the study.

\section{Carotid artery denudation and assessment of reendothelialization}

For assessment of reendothelialization (i.e., endothelial regeneration), mice were anesthetized and the left common carotid artery was subjected to an electric injury starting at the bifurcation point and continuing $4 \mathrm{~mm}$ in the proximal direction as previously described [28, 45]. Five days after injury, mice were killed and $50 \mu \mathrm{l}$ of Evans blue solution (Sigma, Kawasaki, Japan) was applied through the left ventricle. One minute after injection, the vascular system was flushed with $4 \mathrm{ml}$ of $\mathrm{NaCl} 0.9 \%$ to remove excess Evans blue dye from the vasculature. Subsequently, the harvested carotid arteries were mounted on a microscope slide. Blue areas were considered to be denudated and/or damaged, and unstained areas as healthy and/or regenerated. Measurements were computer based and executed by a blinded investigator (AxioVision version 4.5.0 software, Zeiss, Jena, Germany).

\section{Flow cytometry}

Flow cytometry analysis was performed as previously described $[28,30]$. Samples were measured on a FACSCalibur or FACSCanto II (BD Bioscience, Franklin Lakes, USA) and analyzed with FlowJo (Tree Star, Ashland, USA). Dead cells were identified by using a Zombie Aqua ${ }^{\mathrm{TM}}$ Fixable Viability Kit (Biolegend, San Diego USA). Doublets were excluded in every analysis. Samples were stained with anti-sca1-APC (R\&D Systems, 
Minneapolis, USA) anti-flk-1-PE (BD Bioscience, Franklin Lakes, USA), anti-B220-APC (BD Bioscience, Franklin Lakes, USA), anti-IgM-Per-CP/Cy5.5 (BD Bioscience, Franklin Lakes, USA), anti-CD11b-APC/Cy7 (BD Bioscience, Franklin Lakes, USA), anti-CD5-PE (BD Bioscience, Franklin Lakes, USA), anti-sca1-FITC (BD Bioscience, Franklin Lakes, USA), anti-flk1-PE-Cy7 (BD Bioscience, Franklin Lakes, USA), anti-CD3-FITC (BD Bioscience, Franklin Lakes, USA), anti-CD4-PE/Cy 7 (eBioscience, Waltham, USA), anti-CD8-APC (Biolegend, San Diego, USA), anti-sca1-PerCP/Cy5.5 (eBioscience, Waltham, USA), anti-CD11b-PE (BD Bioscience, Franklin Lakes, USA), anti-CD115-APC (Biolegend, San Diego USA), anti-Gr1-FITC (BD Bioscience, Franklin Lakes, USA) and anti-CD45 FITC (BD Bioscience, Franklin Lakes, USA).

\section{Fluorescence-activated cell sorting}

Spleen cells were stained with anti-CD45-FITC (BD Bioscience, Franklin Lakes, USA), anti-sca1-BV421 (BD Bioscience, Franklin Lakes, USA), anti-flk1-PE-Cy7 (BD Bioscience, Franklin Lakes, USA), anti-B220-APC (BD Bioscience, Franklin Lakes, USA), anti-IgM-PerCP/Cy5.5 (BD Bioscience, Franklin Lakes, USA), antiCD11b-APC/Cy7 (BD Bioscience, Franklin Lakes, USA) and anti-CD5-PE (BD Bioscience, Franklin Lakes, USA). Dead cells were identified by using a Zombie Aqua ${ }^{\mathrm{TM}}$ Fixable Viability Kit (Biolegend, San Diego USA) and doublets were excluded.

The following fractions were sorted by using flow cytometry (FACSAria, BD): $\mathrm{CD}^{2} 5^{+}, \mathrm{sca}^{+} / \mathrm{flk} 1^{+}\left(\mathrm{sca}^{+} / \mathrm{flk} 1^{+}\right.$cells);

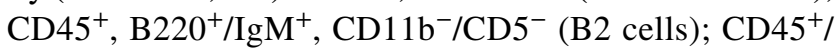

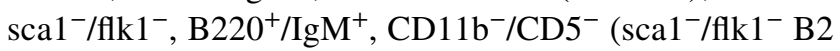
cells).

\section{Mouse surface marker PCR array and RNA-sequencing}

To confirm the identity of sca $1^{+} / \mathrm{flk} 1^{+}$putative EPCs, a mouse surface marker PCR array of isolated sca $1^{+} / \mathrm{flk} 1^{+}$ putative EPCs, conventional B2 cells, and sca1/flk1depleted B2 cells was performed (Cell Surface Markers PCR Array, Qiagen, Hilden, Germany). The PCR array was used in accordance with the manufacturer's instructions. Unsorted spleen cells were used as controls. To get further insights into the identity of $\mathrm{sca} 1^{+} / \mathrm{flk} 1^{+}$putative EPCs, RNA sequencing was performed on the sorted $\mathrm{sca} 1^{+} / \mathrm{flk} 1^{+}$putative EPCs. Fluorescence-activated cell sorting was performed as indicated above. Sorted B2 cells and sca1 ${ }^{-} / \mathrm{flk} 1^{-}$B2 cells were used as controls.

\section{Statistical analysis}

The results are presented as means \pm SEM and were analyzed with the Student's $t$ test. Values of $p \leq 0.05$ were considered significant.

\section{Results}

\section{Increased level of sca $1^{+} / \mathrm{flk} 1^{+}$cells correlates with enhanced endothelial regeneration}

One putative, mouse-specific subset of circulating EPCs is defined as $\mathrm{sca} 1^{+} / \mathrm{flk} 1^{+}$cells. This subset has been repeatedly shown to be associated with vascular health and can be increased with various drugs. Furthermore, the increase of $s c a 1^{+} / f \mathrm{kl} 1^{+}$cells correlates with improved endothelial dysfunction [29]. In a first series of experiments, we administered recombinant granulocyte-colony stimulating factor (G-CSF, Fig. 1a), which is known to mobilize cells of the endogenous stem cell and progenitor cell pools. In two independent experiments, we found elevated levels of sca ${ }^{+} /$ flk $1^{+}$cells in peripheral blood and bone marrow, but a reduction of sca $1^{+} / \mathrm{flk} 1^{+}$cells among splenocytes (Fig. 1b-d). We also inflicted an electric injury of the common carotid artery on some of the mice to assess endothelial regeneration. G-CSF treatment led to increased sca $1^{+} / \mathrm{flk} 1^{+}$cells in the peripheral blood and was associated with improved restoration of the endothelium in the area of damage (Fig. 1e).

\section{Hematopoietic surface markers of lymphocytes and monocytes/macrophages are co-expressed on $\mathrm{sca} 1^{+} / \mathrm{flk} 1^{+}$cells}

Flow cytometry analysis of peripheral blood samples from wild-type mice showed that $\mathrm{sca} 1^{+} / \mathrm{flk} 1^{+}$cells are also positive for CD45 and approximately $70 \%$ of the cells coexpress the B cell surface antigen B4 (CD19) (Fig. 2a, b). There is also a low level of the T-cell co-receptor (CD3) expressed by the cells and approximately $40 \%$ express the macrophage-1 antigen (Mac1 or CD11b, Fig. 2c). When we scrutinized different lymphocyte subsets, $\mathrm{sca} 1^{+} / \mathrm{flk} 1^{+}$cells appeared to be mostly the conventional B2-type (B220 ${ }^{+} /$ $\left.\mathrm{IgM}^{+}, \mathrm{CD} 1 \mathrm{~b}^{-} / \mathrm{CD}^{-}\right) \mathrm{B}$ cells, but there were also some

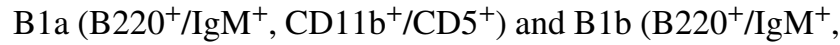
$\left.\mathrm{CD} 1 \mathrm{~b}^{+} / \mathrm{CD}^{-}\right)$cells as well as T-helper (CD4) and cytotoxic (CD8) T cells (Fig. 2d). The analysis of spleen-derived sca $1^{+} / \mathrm{flk} 1^{+}$cells showed the same distribution pattern of Band T-cell subsets as in peripheral blood (Fig. 2e). When we investigated sca $1^{+} / \mathrm{flk} 1^{+}$cells for a possible monocyte/macrophage identity, we found that classical and non-classical monocytes as well as neutrophils did not express significant levels of sca1 and flk1 (Fig. 3a-c). Furthermore, when we 

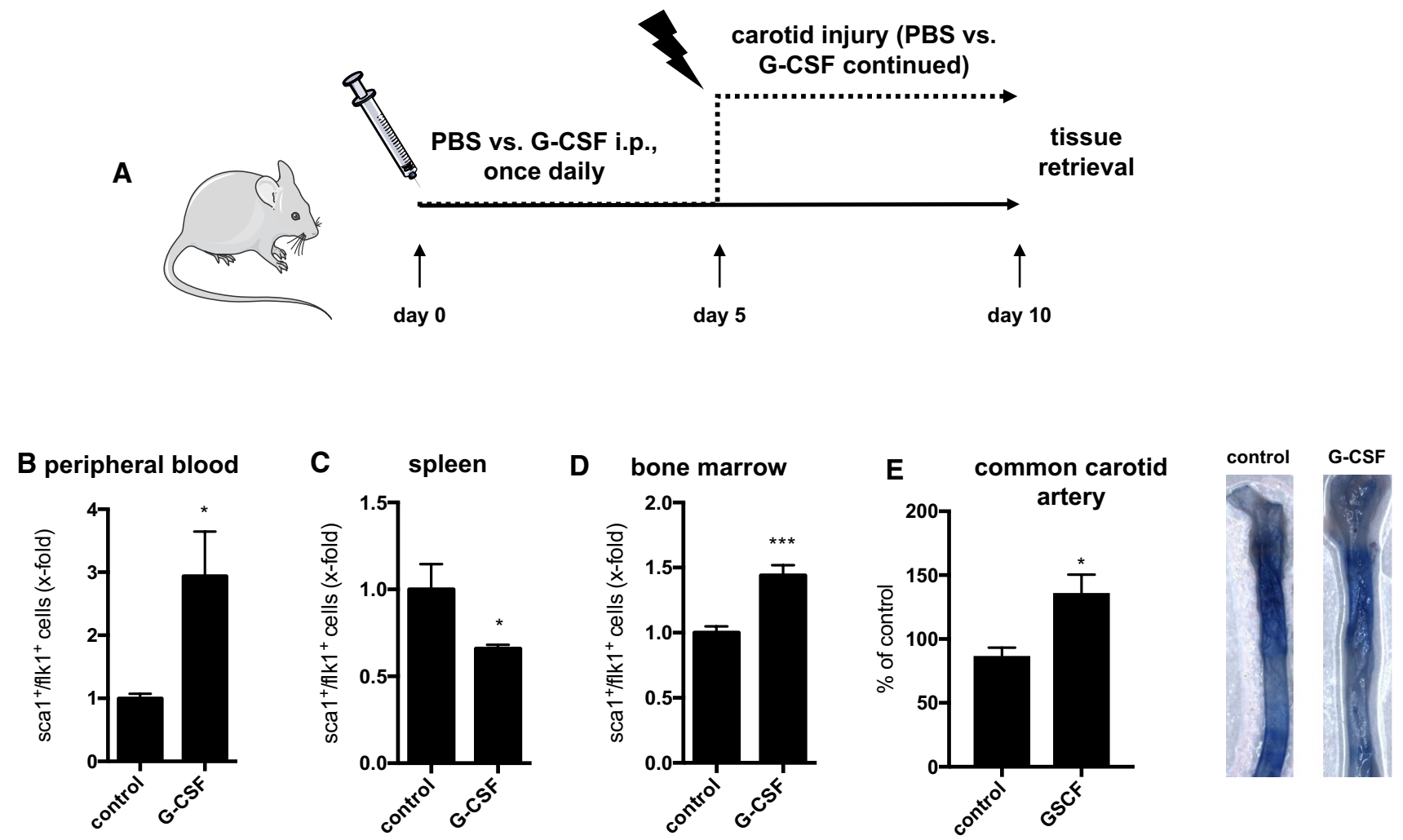

Fig. 1 sca $1^{+} / \mathrm{flk} 1^{+}$cells are pharmacologically increased by G-CSF in the bone marrow and peripheral circulation and correlate with improved endothelial regeneration in the common carotid artery upon injury. a Experimental design to increase $s c a 1^{+} / f \mathrm{kl} 1^{+}$cells by injecting recombinant G-CSF. b-d Quantification of sca $1^{+} / \mathrm{flk} 1^{+}$cells in peripheral blood, spleen, and bone marrow after 10 days of G-CSF treatment $(n=8-10, * p \leq 0.05, * * * \leq 0.001)$. e Endothelial regeneration following electric injury of the common carotid artery during treatment with PBS (control) or G-CSF $(n=4-5 ; * p \leq 0.05)$

cells compared to B2 cells and sca $1^{-} / \mathrm{flk} 1^{-} \mathrm{B} 2$ cells, which are exclusive to B lymphocytes. Furthermore, T-cell markers such as Ctla4, CD401g, and CD3d appeared to be downregulated in these cells (Fig. 5a, b), compared to the controls. However, we also detected a few markers of $\mathrm{T}$ cells, such as CD3g, and monocyte/ macrophages, such as CD163 or Csf1r, to be upregulated in $\mathrm{sca} 1^{+} / \mathrm{flk} 1^{+}$cells (Fig. 5a, b). When we analyzed the gene expression of $\mathrm{sca} 1^{+} / \mathrm{flk} 1^{+}$cells with respect to specific $B$ cell subsets, we found a noticeable upregulation of surface markers that are characteristic for regulatory B cells, such as CD1, CD86, or Cr2 (Fig. 5c). Furthermore, CD38 appeared to be highly upregulated in $\mathrm{sca} 1^{+} / \mathrm{flk} 1^{+}$ cells, which is a surface marker on human regulatory B lymphocytes. To scrutinize the B2 cell-like phenotype of $\mathrm{sca} 1^{+} / \mathrm{flk} 1^{+}$cells and to identify possible key regulated genes, sca $1^{+} / \mathrm{flk} 1^{+}$cells, B2 cells, and $\mathrm{sca} 1^{-} / \mathrm{flk} 1^{-} \mathrm{B} 2$ cells were analyzed by RNA sequencing. In line with our previous results, we found a similar gene expression profile in the three groups, especially with regard to the expression of B cell surface markers (Fig. 6). 
A
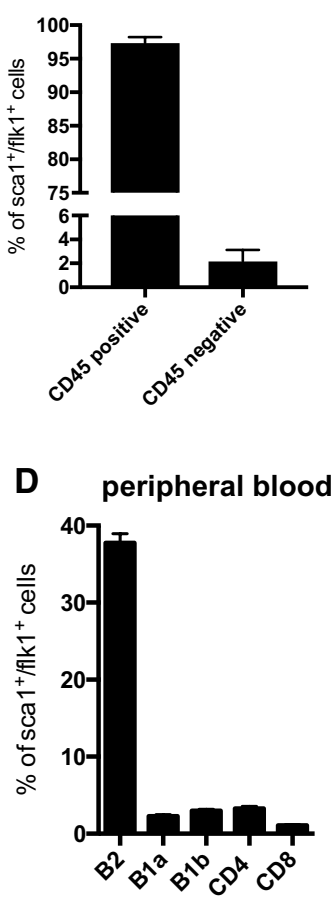

B

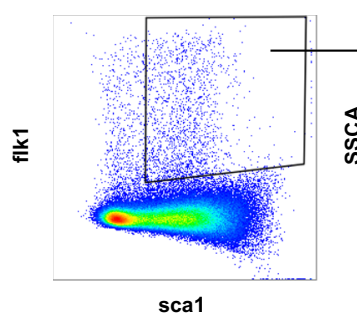

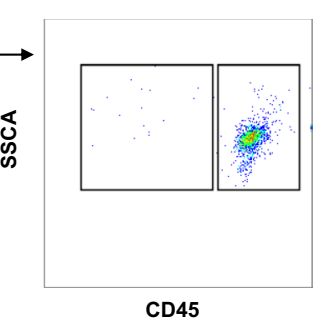

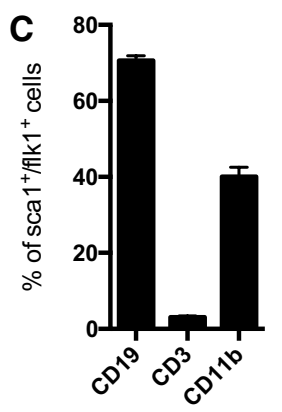

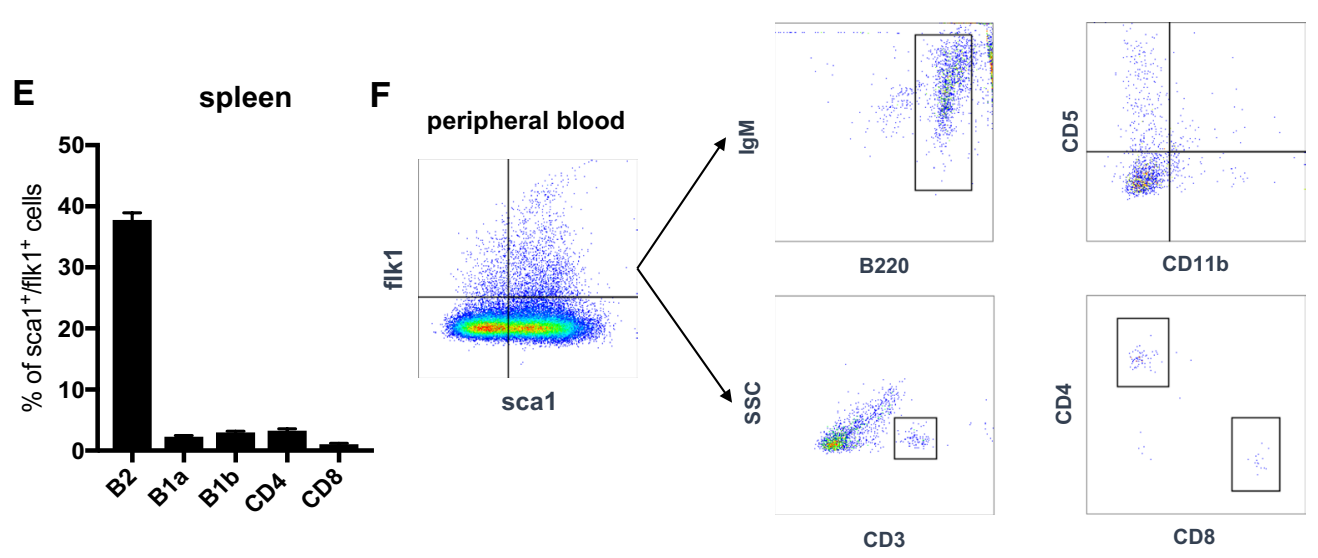

Fig. 2 sca $1^{+} / \mathrm{flk} 1^{+}$cells are hematopoietic cells with lymphocyte and monocyte surface markers. a Quantification of CD45-positive and -negative sca $1^{+} / \mathrm{flk} 1^{+}$cells in peripheral blood in 12 weeks old male C57/B16J mice $(n=5)$. b Representative images of CD45 expression of $\mathrm{sca} 1^{+} / \mathrm{flk} 1^{+}$cells in peripheral blood of 12 -week-old male C57/

\section{The depletion of $\mathrm{B}$ cells including sca $1^{+} / \mathrm{flk} 1^{+}$cells leads to a decline in endothelial regeneration in G-CSF treated wild-type mice}

Finally, we further investigated whether B2- and sca $1^{+} /$ flk $1^{+}$cells may directly impact endothelial regeneration, which had been so far hypothesized by their correlation with endothelial health. We tested reendothelialization after antibody-mediated depletion of $\mathrm{B} 2$ cells including sca ${ }^{+} /$ $\mathrm{flk} 1^{+}$cells, as well as in RAG2-deficient mice, with and without concomitantly administered G-CSF (Fig. 7). The depletion of $\mathrm{B} 2$ cells and $\mathrm{sca} 1^{+} / \mathrm{flk} 1^{+}$cells was verified by flow cytometry in each experiment (Fig. 7a-e). Depletion of $\mathrm{sca} 1^{+} / \mathrm{flk} 1^{+}$cells alone did not affect endothelial regeneration under basal, unstimulated conditions (Fig. 7f). However, when mice were given G-CSF, we found a decline in the endothelial regeneration in the mice that lacked B2- and sca $1^{+} / \mathrm{flk} 1^{+}$cells compared to their littermate controls (Fig. 7f). In RAG2 ${ }^{-1-}$ mice, endothelial regeneration appeared to be enhanced at baseline compared to wild-type mice, which can be explained by the absence of pro- and antiatherogenic influences due to their immunodeficiency [20]. However, the administration of G-CSF did not further
B16J mice. c sca $1^{+} / \mathrm{flk} 1^{+}$cells mainly express the lymphocyte markers CD19 and CD3, and CD11b. d Quantification of B- and T-cell subsets among sca $1^{+} / \mathrm{flk} 1^{+}$cells in peripheral blood, and in (e spleen $(n=5-7)$. f Gating strategy for the investigation of B- and T-cell markers on $\mathrm{sca}^{+} / \mathrm{flk} 1^{+}$cells

improve endothelial regeneration, indicating that the subset of $\mathrm{sca} 1^{+} / \mathrm{flk} 1^{+}$cells, or at least B2 cells, is mandatory for the endothelial-regenerating effect of G-CSF (Fig. 7g).

\section{Discussion}

Since they were first described in 1997 by Asahara et al., a multitude of studies have investigated the impact of putative EPCs on vascular regeneration and atherosclerosis $[1,15$, $29,35,37,42]$. Due to legitimate doubts concerning their identity and function, our study aimed to scrutinize $\mathrm{sca}^{+}{ }^{+} /$ flk $1^{+}$cells, which had thus far been considered to be EPCs $[4,7,9,13,21,32]$.

To demonstrate the higher potential for endothelial regeneration in mice with higher circulating levels of $\mathrm{sca} 1^{+} / \mathrm{flk} 1^{+}$cells, the animals were treated with G-CSF, a well-established mobilizing agent of putative EPCs [17, 19]. As expected, G-CSF treatment led to elevated levels of circulating sca $1^{+} / \mathrm{flk} 1^{+}$cells in the peripheral blood and an enhancement of endothelial regeneration following electric injury of the common carotid artery, which is in line with previous studies by ours and other groups. One study 
A

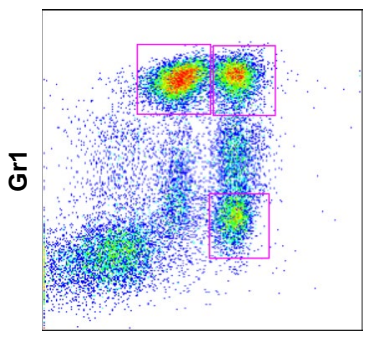

CD115
C Non-classical monocytes

B Classical monocytes in peripheral blood

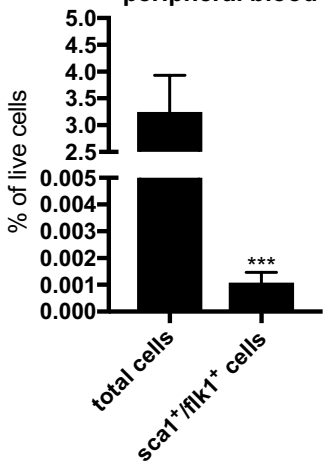

Fig. $3 \mathrm{sca}^{+} / \mathrm{flk} 1^{+}$cells are not monocytes or neutrophils. a Gating strategy to investigate $\mathrm{sca} 1^{+} / \mathrm{flk} 1^{+}$cells among neutrophils $\left(\mathrm{CD} 11 \mathrm{~b}^{+} / \mathrm{Gr} 1^{\text {high }} / \mathrm{CD} 115^{\text {neg }}\right)$, classical $\left(\mathrm{CD} 11 \mathrm{~b}^{+} / \mathrm{Gr} 1^{\text {high }} / \mathrm{CD} 115^{\text {pos }}\right)$, and non-classical $\left(\mathrm{CD} 11 \mathrm{~b}^{+} / \mathrm{Gr} 1^{\text {low}} / \mathrm{CD} 115^{\mathrm{pos}}\right)$ monocytes. Expres-

\section{A peripheral blood}

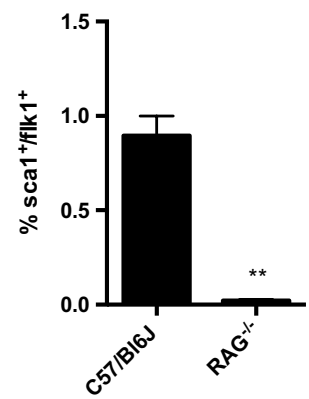

B peripheral blood

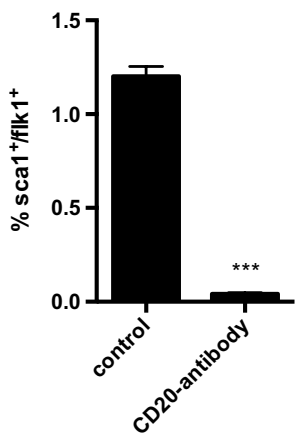

sion of $\mathbf{b}$ classical and $\mathbf{c}$ non-classical monocyte markers is significantly decreased in $\mathrm{sca}^{+} / \mathrm{flk} 1^{+}$cells $(n=9-10$; *** $p \leq 0.001$, $* * * * p \leq 0.0001)$. d Representative flow cytometry images of $\mathrm{sca}^{+} /$ flk $1^{+}$cells after monocyte depletion in C57/B16J mice
Fig. $4 \mathrm{sca}^{+} / \mathrm{flk} 1^{+}$cells are almost undetectable B- and T-celldeficient $\mathrm{RAG}^{-/-}$mice or following B2 cell depletion. a sca $1^{+} / \mathrm{flk}^{+}$ cells are scarcely detectable in the peripheral blood of RAG2-deficient $\left(\mathrm{RAG}^{-/-}\right)$mice. $\mathbf{b}$ The depletion of B2 cells with anti-CD20

demonstrated that the application of G-CSF leads to accelerated endothelial regeneration and neointimal formation after wire-mediated vascular injury of the femoral artery in C57/ Bl6J mice [43]. Studies from our group have shown that mobilization of $\mathrm{sca} 1^{+} / \mathrm{flk} 1^{+}$cells with different mobilizing
D

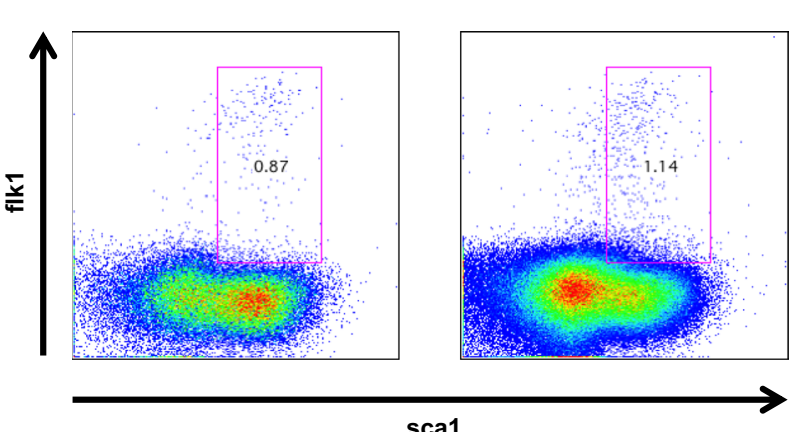

sca1 non-classical monocytes

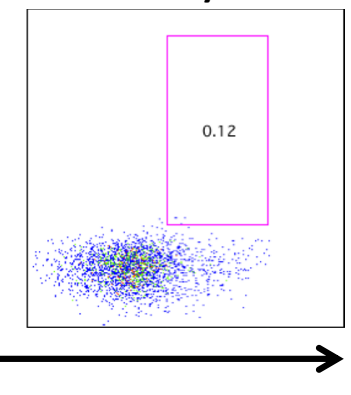

\section{sca1}




\section{A}

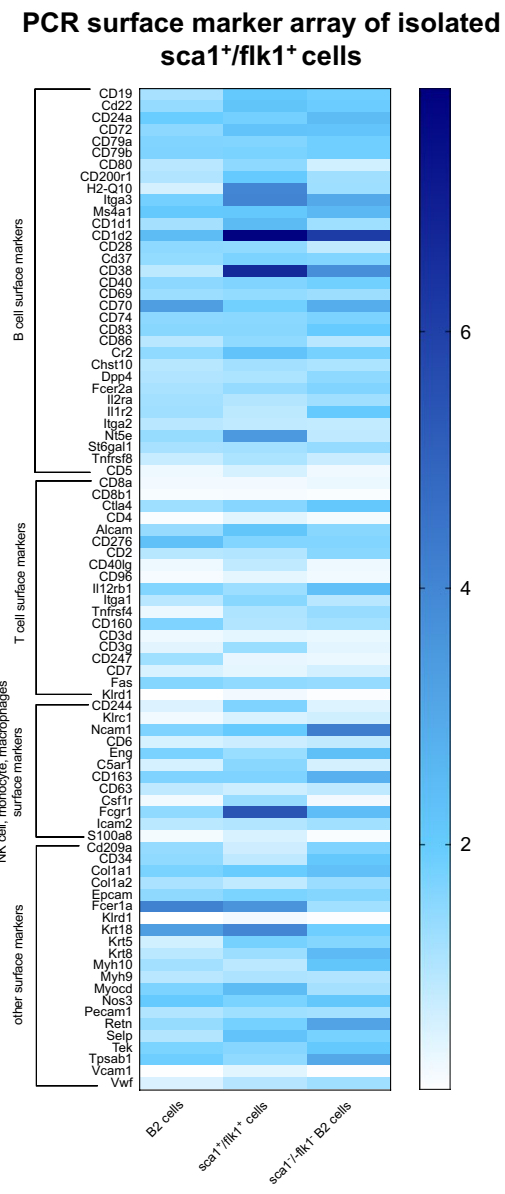

B

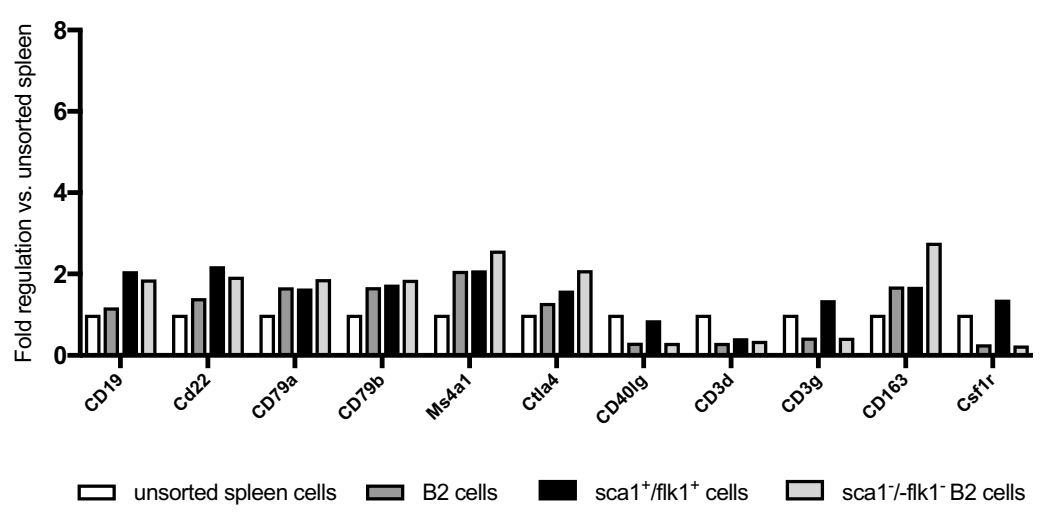

C

Regulatory B cell surface markers

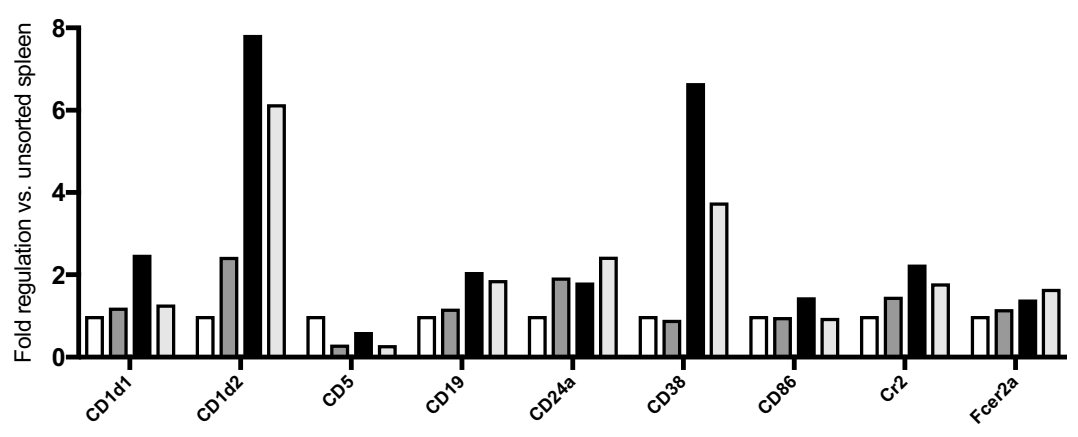

Fig. 5 Expression of B cell surface markers is similar in purified $\mathrm{sca} 1^{+} / \mathrm{flk} 1^{+}$cells compared to conventional B2 cells and $\mathrm{sca} 1^{-} / \mathrm{flk} 1^{-}$ B2 cells. a Heat map of surface-marker mRNA expression in spleenderived $\mathrm{sca} 1^{+} / \mathrm{flk} 1^{+}$cells, B2 cells and $\mathrm{sca} 1^{-} / \mathrm{flk} 1^{-} \mathrm{B} 2$ cells. Cells were isolated by fluorescence activated cell sorting and compared to

cells are at least partially mobilized from the bone marrow and that the ability to mobilize these cells declines with age and the severity of atherosclerosis $[27,28,30]$. When we analyzed sca $1^{+} / \mathrm{flk} 1^{+}$cells with respect to their identity, we found that the majority of sca $1^{+} / \mathrm{flk} 1^{+}$cells expressed CD45. This result has been reported before by Wheat et al. who studied the effects of acrolein inhalation on sca $1^{+} / f \mathrm{lk} 1^{+}$cells in mice and reported that these cells were positive for CD45 [39]. We analyzed hematopoietic lineage markers, which revealed the co-expression of lymphocyte and monocyte/ macrophage markers on $\mathrm{sca} 1^{+} / \mathrm{flk} 1^{+}$cells, with a preponderance of conventional B2 lymphocytes. To confirm the predominant B cell-like phenotype of $s c a 1^{+} / \mathrm{flk} 1^{+}$cells, we used flow cytometry-based cell sorting and analyzed their intracellular transcripts by mRNA profiling and RNA sequencing. We detected a similar expression of B cell surface markers in sca $1^{+} / \mathrm{flk} 1^{+}$cells compared to conventional B2 cells and sca1/flk1-depleted B2 cells. We also detected an normal spleen cells. b Expression of B cell, T cell, and monocyte/ macrophage cell-surface markers and $\mathbf{c}$ regulatory $\mathrm{B}$ cell markers in $\mathrm{sca} 1^{+} / \mathrm{flk} 1^{+}$cells, B2 cells, sca $1^{-} / \mathrm{flk} 1^{-} \mathrm{B} 2$ cells, and unsorted spleen cells. Samples of isolated $\mathrm{sca} 1^{+} / \mathrm{flk} 1^{+}, \mathrm{B} 2$ cells, and $\mathrm{sca} 1^{-} / \mathrm{flk} 1^{-} \mathrm{B} 2$ cells were pooled from $n=10$

upregulation of scattered T-cell and monocyte/macrophage markers, which strengthens our flow cytometry data. However, there was a striking dominance of B2 cell markers. Finally, the depletion of lymphocytes in $\mathrm{RAG}^{-/-}$mice, and especially B2 cell depletion with anti-CD20, was associated with a concomitant, total depletion of $\mathrm{sca} 1^{+} / \mathrm{flk} 1^{+}$cells, whereas monocyte depletion did not affect $\mathrm{sca} 1^{+} / \mathrm{flk} 1^{+}$cells in a significant way.

B cells are important modulators of atherosclerotic disease that act by antibody secretion, production of cytokines or T-cell regulation (see reviews [23, 24]). The subset of B2 cells is a heterogeneous population, comprising follicular, marginal zone, and regulatory B cells with different impacts on lesion development [18]. Whereas Kyaw et al. suggested an overall proatherogenic role for B2 cells, Nus et al. showed that marginal zone $\mathrm{B}$ cells protect from lesion development by inhibiting a proatherogenic response of $\mathrm{T}$-follicular helper cells $[11,16]$. Strom et al. identified a lymph node-derived 
Fig. 6 Analysis of $\mathrm{sca}^{+} /$ flk $1^{+}$cells by RNA sequencing confirms their predominant B cell-like phenotype. Heat map of surface marker mRNA expression in spleen-derived $\mathrm{sca} 1^{+} / \mathrm{flk} 1^{+}$cells, B2 cells, $\mathrm{sca} 1^{-} / \mathrm{flk} 1^{-} \mathrm{B} 2$ cells, and unsorted spleen cells is shown. Samples were analyzed by using RNA sequencing. Samples of isolated $\mathrm{sca} 1^{+} / \mathrm{flk} 1^{+}$, B2 cells, and sca1 ${ }^{-} / \mathrm{flk} 1^{-} \mathrm{B} 2$ cells were pooled from $n=10$
RNA-sequencing of isolated sca1+/flk1+ cells

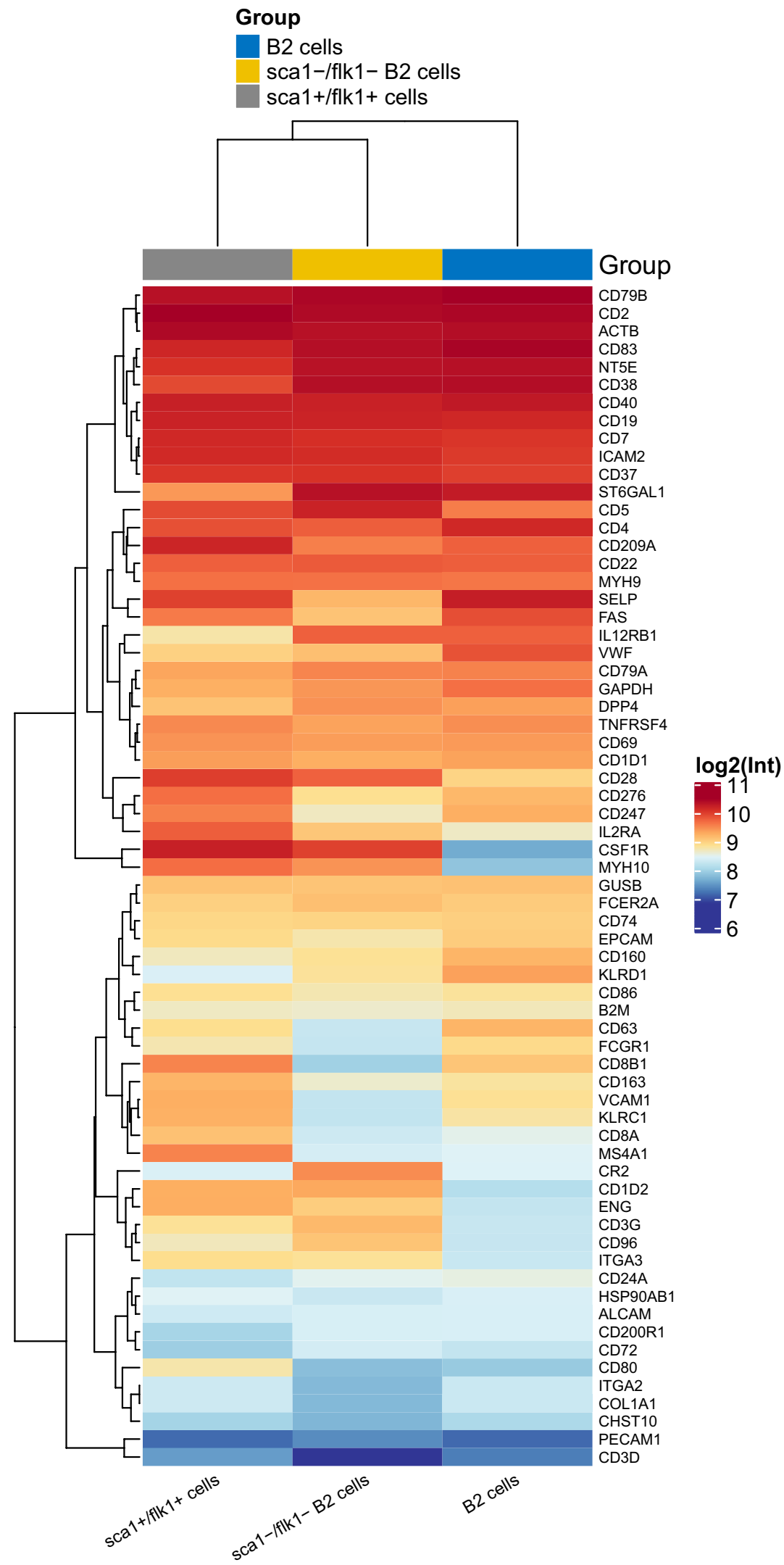




\section{A Peripheral blood}

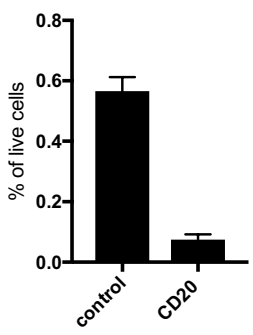

\section{B Peripheral blood}

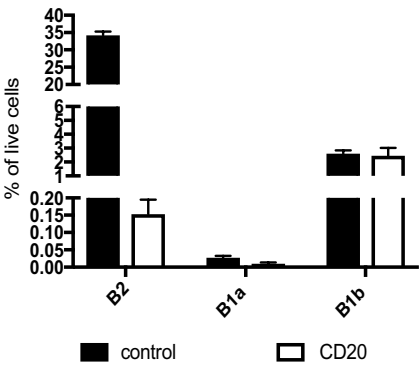

C Peripheral blood

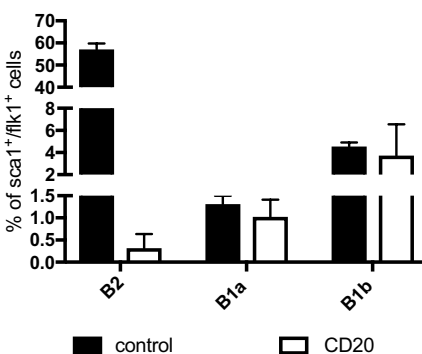

D

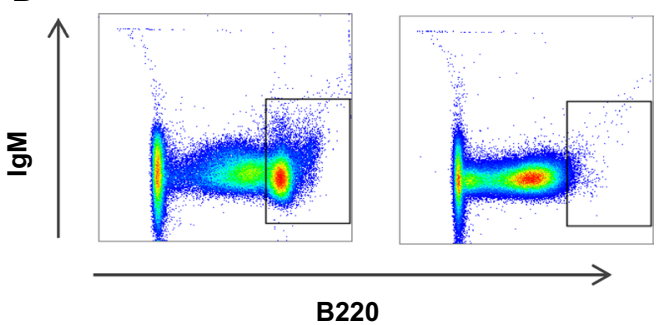

E
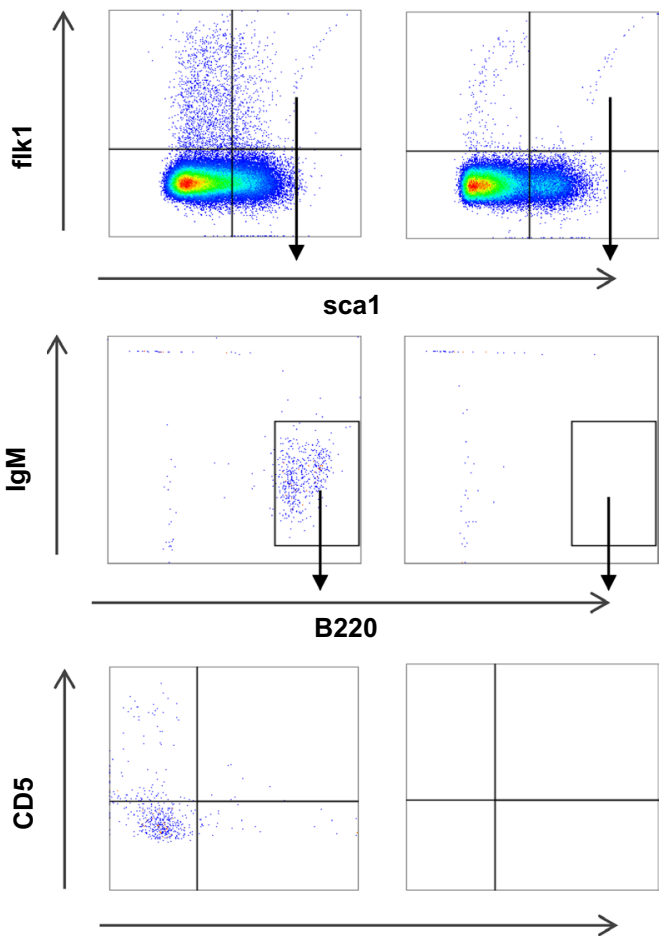

CD11b
F Endothelial regeneration

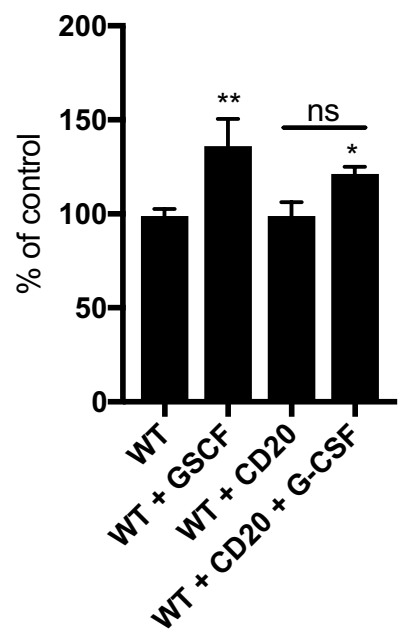

G Endothelial regeneration

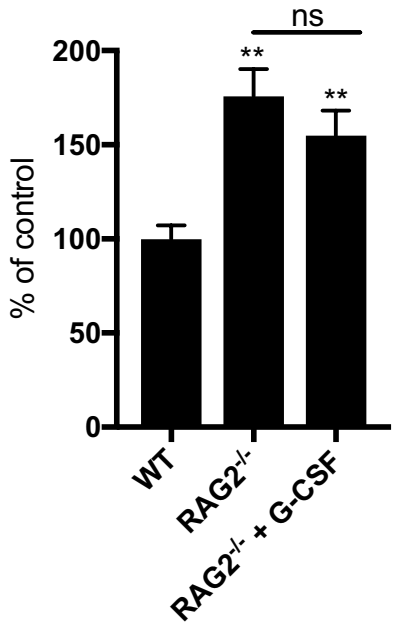

Fig. $7 \mathrm{sca} 1^{+} / \mathrm{flk} 1^{+}$cells are mandatory for endothelial regeneration after $\mathrm{G}-\mathrm{CSF}$ treatment. a sca $1^{+} / \mathrm{flk} 1^{+}$cells in peripheral blood after B2 cell depletion $(n=7-10)$. b Subsets of B cells in peripheral blood after administration of G-CSF and B2 cell depletion $(n=7-10)$. c Subsets of $\mathrm{sca} 1^{+} / \mathrm{flk} 1^{+} \mathrm{B}$ cells in peripheral blood after administration of G-CSF and B2 cell depletion $(n=7-10)$. d Representative image of $\mathrm{B} 2$ cell depletion after administration of the anti-CD20 antibody.

subset of regulatory B2 cells that reduced neointima formation by secreting IL-10 [31]. The relevance of IL-10 production was also highlighted by Ponnuswamy et al., who demonstrated a synergy between angiotensin II and BAFF, resulting in an induction of atheroprotective regulatory B2 cells [18]. Interestingly, we found several surface markers that are also expressed on regulatory B cells, such as $\mathrm{CD} 1, \mathrm{Cr} 2$, or $\mathrm{CD} 86$, to be upregulated in $\mathrm{sca} 1^{+} / \mathrm{flk} 1^{+}$cells $[14,22]$. Furthermore, we found a strong upregulation of CD38. CD38 is a transmembrane receptor and ectoenzyme, which is found on several B cell subsets and is involved in e The gating strategy used to analyze $s c a 1^{+} / \mathrm{flk} 1^{+} \mathrm{B}$ cell subsets in peripheral blood after B2 cell depletion. f Endothelial regeneration after administration of G-CSF, administration of G-CSF and B2 cell depletion, or B2 cell depletion alone $(n=5-14, * p \leq 0.05, * * p \leq 0.01$, $n s$ not significant). $\mathrm{g}$ Endothelial regeneration in $\mathrm{RAG}^{-/-}$mice at baseline and after administration of G-CSF $(n=5, * * p \leq 0.01)$

apoptosis, cell differentiation, proliferation, and activation [34]. In humans, regulatory $\mathrm{CD} 19^{+}, \mathrm{CD} 24^{\mathrm{hi}}, \mathrm{CD} 38^{\mathrm{hi}} \mathrm{B}$ cells have been shown to inhibit the production of proinflammatory cytokines by $\mathrm{CD} 4^{+} \mathrm{T}$ cells [2]. A murine subset of regulatory $\mathrm{B}$ cells that express CD38 has not yet been described $[14,22]$.

Having identified sca $1^{+} / \mathrm{flk} 1^{+}$cells as mainly B2 cells, we wanted to investigate their impact on endothelial regeneration. Therefore, we tested whether the depletion of $\mathrm{B} 2$ cells and sca $1^{+} / \mathrm{flk} 1^{+}$cells would affect reendothelialization. In mice treated with an anti-CD20 antibody, 
the benefit on reendothelialization from G-CSF treatment declined. In RAG2 $2^{-/}$mice, which lack mature $\mathrm{B}$ and $\mathrm{T}$ lymphocytes as well as sca $1^{+} / \mathrm{flk} 1^{+}$cells, G-CSF treatment had no effect on endothelial regeneration. These data suggest that G-CSF-induced reendothelialization depends on B2 cells, which include sca $1^{+} / \mathrm{flk} 1^{+}$cells.

One possible mechanism could be an enhanced mobilization of protective $\mathrm{sca} 1^{+} / \mathrm{flk} 1^{+} \mathrm{B} 2$ cells into the peripheral circulation. Studies from cancer research have already demonstrated the angiogenic potential of B cells [3]. B cells are able to promote angiogenesis in lymph nodes by paracrine secretion of VEGF [26]. STAT3 activation in B cells contributes to tumor progression by enhancing angiogenesis. Co-culturing endothelial cells with naïve spleen-derived B cells was associated with a significant increase in tube formation [41]. In our study, we found surface markers of regulatory B cells upregulated in $\mathrm{sca}^{+} /$ $\mathrm{flk} 1^{+}$cells. One hypothesis is that IL-10 signaling is a possible mechanism by which sca $1^{+} / \mathrm{flk} 1^{+}$cells contribute to endothelial regeneration [22]. Interestingly, it has been reported that G-CSF itself is able to promote angiogenesis [10]. However, since endothelial regeneration declined in G-CSF-treated wild-type mice after B2 cell depletion, our data raise doubts about that mode of action for G-CSF.

One limitation is that anti-CD20-treatment depletes the whole subset of $\mathrm{B} 2$ cells including sca $1^{+} / \mathrm{flk} 1^{+}$cells. However, the focus of our study was to clarify the identity and function of sca $1^{+} / \mathrm{flk} 1^{+}$cells.

In conclusion, our study shows that $\mathrm{sca} 1^{+} / \mathrm{flk} 1^{+}$cells are not EPCs, but lymphocytes instead, comprising mainly B2 lymphocytes. Although they are not true vascular progenitor cells, B cells do contribute to G-CSF-mediated endothelial regeneration. Furthermore, $\mathrm{sca} 1^{+} / \mathrm{flk} 1^{+} \mathrm{B}$ cells were confirmed as a biomarker that correlates with reendothelialization. Their contribution to endothelial regeneration still needs to be elucidated and should be addressed in future studies.

Acknowledgements Open Access funding provided by Projekt DEAL. This work was supported by BONFOR Bonn. We thank Anna Flender and Theresa Schmitz for technical assistance and Andreas Dolf and Peter Wurst of the Bonn Flow Cytometry Core Facility for their support. We also thank André Heimbach of the Next Generation Sequencing Core Facility and Andreas Buness of the Core Unit for Bioinformatics Data Analysis for their support.

Author contributions ES, MS: data collection, analysis, and writing of manuscript; WBEMvW, MH, SN, AZ: data collection; NW, TR, GN, SW, SZ: critical review.

\section{Compliance with ethical standards}

Conflict of interest The authors declare that they have no conflict of interests.
Open Access This article is licensed under a Creative Commons Attribution 4.0 International License, which permits use, sharing, adaptation, distribution and reproduction in any medium or format, as long as you give appropriate credit to the original author(s) and the source, provide a link to the Creative Commons licence, and indicate if changes were made. The images or other third party material in this article are included in the article's Creative Commons licence, unless indicated otherwise in a credit line to the material. If material is not included in the article's Creative Commons licence and your intended use is not permitted by statutory regulation or exceeds the permitted use, you will need to obtain permission directly from the copyright holder. To view a copy of this licence, visit http://creativecommons.org/licenses/by/4.0/.

\section{References}

1. Asahara T, Murohara T, Sullivan A, Silver M, Van Der Zee R, Li T, Witzenbichler B, Schatteman G, Isner JM (1997) Isolation of putative progenitor endothelial cells for angiogenesis. Science 275:964-967. https://doi.org/10.1126/science.275.5302.964

2. Blair P, Noreña L, Flores-Borja F, Rawlings D, Isenberg D, Ehrenstein M, Mauri C (2010) CD19(+)CD24(hi)CD38(hi) B cells exhibit regulatory capacity in healthy individuals but are functionally impaired in systemic lupus erythematosus patients. Immunity 32:129-140. https://doi.org/10.1016/j.immuni.2009.11.009

3. Bruno A, Pagani A, Pulze L, Albini A, Dallaglio K, Noonan DM, Mortara L (2014) Orchestration of angiogenesis by immune cells. Front Oncol 4:1-13. https://doi.org/10.3389/fonc.2014.00131

4. Case J, Mead LE, Bessler WK, Prater D, White HA, Saadatzadeh MR, Bhavsar JR, Yoder MC, Haneline LS, Ingram DA (2007) Human CD34+AC133+VEGFR-2+ cells are not endothelial progenitor cells but distinct, primitive hematopoietic progenitors. Exp Hematol 35:1109-1118. https://doi.org/10.1016/j.exphe m.2007.04.002

5. Davignon J, Ganz P (2004) Role of endothelial dysfunction in atherosclerosis. Circulation 109:27-32. https://doi.org/10.1161/01. CIR.0000131515.03336.f8

6. Du F, Zhou J, Gong R, Huang X, Pansuria M, Virtue A, Li X, Wang H, Yang X-F (2012) Endothelial progenitor cells in atherosclerosis. Front Biosci 17:2327-2349. https://doi. org/10.2741/4055

7. Fadini GP, Losordo D, Dimmeler S (2012) Critical reevaluation of endothelial progenitor cell phenotypes for therapeutic and diagnostic use. Circ Res 110:624-637. https://doi.org/10.1161/CIRCR ESAHA.111.243386.Critical

8. Friedrich EB, Walenta K, Scharlau J, Nickenig G, Werner N (2006) CD34-/CD133+/VEGFR-2+ endothelial progenitor cell subpopulation with potent vasoregenerative capacities. Circ Res 98:20-25. https://doi.org/10.1161/01.RES.0000205765.28940.93

9. Hagensen MK, Shim J, Thim T, Falk E, Bentzon JF (2010) Circulating endothelial progenitor cells do not contribute to plaque endothelium in murine atherosclerosis. Circulation 121:898-905. https://doi.org/10.1161/CIRCULATIONAHA.109.885459

10. Huang H, Zhang Q, Liu J, Hao H, Jiang C, Han W (2017) Granulocyte-colony stimulating factor (G-CSF) accelerates wound healing in hemorrhagic shock rats by enhancing angiogenesis and attenuating apoptosis. Med Sci Monit. https://doi.org/10.12659/ MSM.904988

11. Kyaw T, Tay C, Khan A, Dumouchel V, Cao A, To K, Kehry M, Dunn R, Agrotis A, Tipping P, Bobik A, Toh B (2010) Conventional $\mathrm{B} 2 \mathrm{~B}$ cell depletion ameliorates whereas its adoptive transfer aggravates atherosclerosis. J Immunol 185:4410-4419. https://doi.org/10.4049/jimmunol.1000033 
12. Libby P, Ridker PM, Hansson GK (2011) Progress and challenges in translating the biology of atherosclerosis. Nature 473:317-325. https://doi.org/10.1038/nature10146

13. Madonna R, De Caterina R (2015) Circulating endothelial progenitor cells: do they live up to their name? Vasc Pharmacol 67:2-5. https://doi.org/10.1016/j.vph.2015.02.018

14. Mauri C, Menon M (2015) The expanding family of regulatory B cells. Int Immunol 27:479-486. https://doi.org/10.1093/intimm/ dxv038

15. Medina R, Barber C, Sabatier F, Dignat-George F, Melero-Martin J, Khosrotehrani K, Ohneda O, Randi A, Chan J, Yamaguchi T, Van Hinsbergh V, Yoder M, Stitt A (2017) Endothelial progenitors: a consensus statement on nomenclature. Stem Cells Transl Med 6:1316-1320. https://doi.org/10.1002/sctm.16-0360

16. Nus M, Sage AP, Lu Y, Masters L, Lam BYH, Newland S, Weller S, Tsiantoulas D, Raffort J, Marcus D, Finigan A, Kitt L, Figg N, Schirmbeck R, Kneilling M, Yeo GSH, Binder CJ, De La Pompa JL, Mallat Z (2017) Marginal zone B cells control the response of follicular helper T cells to a high-cholesterol diet. Nat Med 23:601-610. https://doi.org/10.1038/nm.4315

17. Petit I, Szyper-Kravitz M, Nagler A, Lahav M, Peled A, Habler L, Ponomaryov T, Taichman RS, Arenzana-Seisdedos F, Fujii N, Sandbank J, Zipori D, Lapidot T (2002) G-CSF induces stem cell mobilization by decreasing bone marrow SDF-1 and up-regulating CXCR4. Nat Immunol 3:687-694. https://doi.org/10.1038/ni813

18. Ponnuswamy P, Joffre J, Herbin O, Esposito B, Laurans L, Binder CJ, Tedder TF, Zeboudj L, Loyer X, Giraud A, Zhang Y, Tedgui A, Mallat Z, Ait-Oufella H (2017) Angiotensin II synergizes with BAFF to promote atheroprotective regulatory B cells. Sci Rep 7:110. https://doi.org/10.1038/s41598-017-04438-6

19. Powell TM, Paul JD, Hill JM, Thompson M, Benjamin M, Rodrigo M, Mccoy JP, Read EJ, Khuu HM, Leitman SF, Finkel T, Cannon R (2005) Granulocyte colony-stimulating factor mobilizes functional endothelial progenitor cells in patients with coronary artery disease. Arterioscler Thromb Vasc Biol 25:296-301. https://doi. org/10.1161/01.ATV.0000151690.43777.e4

20. Reardon CA, Blachowicz L, White T, Cabana V, Wang Y, Lukens J, Bluestone J, Getz GS (2001) Effect of immune deficiency on lipoproteins and atherosclerosis in male Apolipoprotein E-deficient mice. Arterioscler Thromb Vasc Biol 21:1011-1016. https://doi. org/10.1161/01.atv.21.6.1011

21. Richardson MR, Yoder MC (2011) Endothelial progenitor cells: quo vadis? J Mol Cell Cardiol 50:266-272. https://doi.org/10.1016/j. yjmcc.2010.07.009

22. Rosser EC, Mauri C (2015) Perspective regulatory B cells: origin, phenotype, and function. Immunity 42:607-612. https://doi. org/10.1016/j.immuni.2015.04.005

23. Sage AP, Mallat Z (2014) Multiple potential roles for B cells in atherosclerosis. Ann Med 46:297-303. https://doi.org/10.3109/07853 890.2014.900272

24. Sage AP, Tsiantoulas D, Binder CJ, Mallat Z (2019) The role of B cells in atherosclerosis. Nat Rev Cardiol 16:180-196. https://doi. org/10.1038/s41569-018-0106-9

25. Schmidt-Lucke C, Rössig L, Fichtlscherer S, Vasa M, Britten M, Kämper U, Dimmeler S, Zeiher AM (2005) Reduced number of circulating endothelial progenitor cells predicts future cardiovascular events: proof of concept for the clinical importance of endogenous vascular repair. Circulation 111:2981-2987. https://doi.org/10.1161/ CIRCULATIONAHA.104.504340

26. Shrestha B, Hashiguchi T, Ito T, Miura N, Takenouchi K, Oyama Y, Kawahara K, Tancharoen S, Ki-i Y, Arimura N, Yoshinaga N, Noma S, Shrestha C, Nitanda T, Kitajima S, Arimura K, Sato M, Sakamoto T, Maruyama I (2010) B cell-derived vascular endothelial growth factor A promotes lymphangiogenesis and high endothelial venule expansion in lymph nodes. J Immunol 184:4819-4826. https://doi. org/10.4049/jimmunol.0903063
27. Steinmetz M, Brouwers C, Nickenig G, Wassmann S (2010) Synergistic effects of telmisartan and simvastatin on endothelial progenitor cells. J Cell Mol Med 14:1645-1656. https://doi.org/10.111 1/j.1582-4934.2009.00829.x

28. Steinmetz M, Lucanus E, Zimmer S, Nickenig G, Werner N (2015) Mobilization of sca1/flk-1 positive endothelial progenitor cells declines in apolipoprotein E-deficient mice with a high-fat diet. J Cardiol 66:532-538. https://doi.org/10.1016/j.jjcc.2015.02.008

29. Steinmetz M, Nickenig G, Werner N (2010) Endothelial-regenerating cells: an expanding universe. Hypertension 55:593-599. https ://doi.org/10.1161/HYPERTENSIONAHA.109.134213

30. Steinmetz M, Pelster B, Lucanus E, Arnal JF, Nickenig G, Werner N (2013) Atorvastatin-induced increase in progenitor cell levels is rather caused by enhanced receptor activator of NF-kappaB ligand (RANKL) cell proliferation than by bone marrow mobilization. J Mol Cell Cardiol 57:32-42. https://doi.org/10.1016/j.yjmcc .2012 .12 .018

31. Strom AC, Cross AJ, Cole JE, Blair PA, Leib C, Goddard ME, Rosser EC, Park I, Hultgårdh Nilsson A, Nilsson J, Mauri C, Monaco C (2015) B regulatory cells are increased in hypercholesterolaemic mice and protect from lesion development via IL-10. Thromb Haemost 114:835-847. https://doi.org/10.1160/ TH14-12-1084

32. Timmermans F, Plum J, Yoder MC, Ingram DA, Vandekerckhove B, Case J (2009) Endothelial progenitor cells: identity defined? J Cell Mol Med 13:87-102. https://doi.org/10.111 1/j.1582-4934.2008.00598.x

33. Vasa M, Fichtlscherer S, Aicher A, Adler K, Urbich C, Martin H, Zeiher AM, Dimmeler S (2001) Number and migratory activity of circulating endothelial progenitor cells inversely correlate with risk factors for coronary artery disease. Circ Res 89:e1-e7. https://doi. org/10.1161/hh1301.093953

34. Vences-Catalán F, Santos-Argumedo L (2011) CD38 through the life of a murine B lymphocyte. IUBMB Life 63:840-846. https:// doi.org/10.1002/iub.549

35. Wassmann S, Werner N, Czech T, Nickenig G (2006) Improvement of endothelial function by systemic transfusion of vascular progenitor cells. Circ Res 99:e74-83. https://doi.org/10.1161/01.RES.00002 46095.90247.d4

36. Werner N, Junk S, Laufs U, Link A, Walenta K, Bohm M, Nickenig G (2003) Intravenous transfusion of endothelial progenitor cells reduces neointima formation after vascular injury. Circ Res 93:e17-24. https://doi.org/10.1161/01.RES.0000083812.30141.74

37. Werner N, Kosiol S, Schiegl T, Ahlers P, Walenta K, Link A, Böhm M, Nickenig G (2005) Circulating endothelial progenitor cells and cardiovascular outcomes. N Engl J Med 353:999-1007. https://doi. org/10.1056/NEJMoa043814

38. Werner N, Nickenig G (2007) Endothelial progenitor cells in health and atherosclerotic disease. Ann Med 39:82-90. https://doi. org/10.1080/07853890601073429

39. Wheat LA, Haberzettl P, Hellmann J, Baba SP, Bertke M, Lee J, McCracken J, O’Toole TE, Bhatnagar A, Conklin DJ (2011) Acrolein inhalation prevents vascular endothelial growth factorinduced mobilization of Flk-1+/Sca-1+ cells in mice. Arterioscler Thromb Vasc Biol 31:1598-1606. https://doi.org/10.1161/ATVBA HA.111.227124

40. Xiao Q, Zeng L, Zhang Z, Margariti A, Ali ZA, Channon KM, Xu $\mathrm{Q}, \mathrm{Hu}$ Y (2006) Sca-1+ progenitors derived from embryonic stem cells differentiate into endothelial cells capable of vascular repair after arterial injury. Arterioscler Thromb Vasc Biol 26:2244-2251. https://doi.org/10.1161/01.ATV.0000240251.50215.50

41. Yang C, Lee H, Pal S, Jove V, Deng J, Zhang W, Hoon DS, Wakabayashi M, Forman S, Yu H (2013) B cells promote tumor progression via STAT3 regulated-angiogenesis. PLoS ONE 8:1-10. https ://doi.org/10.1371/journal.pone.0064159 
42. Yoder MC (2017) Endothelial stem and progenitor cells (stem cells): (2017 Grover Conference Series). Pulm Circ 8:1-9. https:// doi.org/10.1177/2045893217743950

43. Yoshioka T, Takahashi M, Shiba Y, Suzuki C, Morimoto H, Izawa A, Ise H, Ikeda U (2006) Granulocyte colony-stimulating factor (G-CSF) accelerates reendothelialization and reduces neointimal formation after vascular injury in mice. Cardiovasc Res 70:61-69. https://doi.org/10.1016/j.cardiores.2005.12.013

44. Ziegelhoeffer T, Fernandez B, Kostin S, Heil M, Voswinckel R, Helisch A, Schaper W (2004) Bone marrow-derived cells do not incorporate into the adult growing vasculature. Circ Res 94:230 238. https://doi.org/10.1161/01.RES.0000110419.50982.1C

45. Zimmer S, Steinmetz M, Asdonk T, Motz I, Coch C, Hartmann E, Barchet W, Wassmann S, Hartmann G, Nickenig G (2011) Activation of endothelial toll-like receptor 3 impairs endothelial function. Circ Res 108:1358-1366. https://doi.org/10.1161/CIRCRESAHA .111 .243246 